Article

\title{
Exploring the Contribution of Grassroots Innovations to Justice: Using the Capability Approach to Normatively Address Bottom-Up Sustainable Transitions Practices
}

\author{
Sergio Belda-Miquel ${ }^{1, *(\mathbb{D}}$, Victoria Pellicer-Sifres ${ }^{2}$ and Alejandra Boni ${ }^{3}(\mathbb{C}$ \\ 1 Departament de Comercialització i Investigació de Mercats, Universitat de València, 46022 Valencia, Spain \\ 2 Institute INGENIO (CSIC-UPV), Universitat Politècnica de València and Las Naves \\ (Ajuntament de València), 46022 Valencia, Spain; vicpelsi@upv.es \\ 3 Institute INGENIO (CSIC-UPV), Universitat Politècnica de València, 46022 Valencia, Spain; aboni@dpi.upv.es \\ * Correspondence: sergio.belda@uv.es
}

Received: 27 March 2020; Accepted: 28 April 2020; Published: 30 April 2020

check for updates

\begin{abstract}
There is growing interest in the potential of grassroots innovations for the transition towards more just and sustainable societies. Nevertheless, there is lack of clear normative discussion regarding these processes. The paper strives to propose and test a framework that enables an analysis of how and in which sense specific grassroots innovation processes may be contributing to the construction of more just societies. To this end, we connect elements of the multi-level perspective on sociotechnical transitions (frequently used in the analysis of grassroots innovations) with elements of the capability approach, which offers a multi-dimensional perspective to justice. The framework is used to address two purposively selected empirical cases in two key sectors in Spain: an energy cooperative and a food purchasing group. We draw on the information of 25 individual interviews with members of these two cases, on observation, and on secondary sources. Information was processed by means of a qualitative content analysis. We draw on predefined categories from the framework, which was refined during the analysis. The paper illustrates that grassroots innovations may be contributing to justice in several aspects: they expand capabilities in different dimensions, improve public reasoning processes, and create better structural conditions for human flourishing. Nevertheless, these processes are not free of tensions and contradictions.
\end{abstract}

Keywords: grassroots innovations; social innovation; justice; capability approach; socio-technical transitions; food groups; energy cooperatives; sustainability

\section{Introduction}

Movements creating alternative everyday life practices as a form of political action have gained increasing attention in recent decades [1,2]. They may be one of the most emblematic transformative movements in present times, creating "counter-flows of democratic power and more sustainable systems and flows of food, energy, water, and materials through local communities and environment" [3] (p. 223).

As state power is shifting towards other stakeholders with no democratic control, addressing social change directly through the politicisation of everyday life is becoming an increasingly relevant strategy [2]. However, the phenomenon is not new, it having been known by various names [4], from "life politics" [5] to "environmental democracy 2.0" [3]. Scholars have highlighted key issues regarding these movements: their focus on action and on the local arena to challenge global structures; their 
prefigurative politics; their radical and bottom-up forms of democratic political participation [2,3]; or the creation of political meanings, knowledge, and alternative forms of social organisation [6].

The focus on everyday life and bottom-up processes for building alternative systems has also been adopted in the field of innovation. In this line, the idea of "grassroots innovation" has been attracting increasingly attention. There is a growing interest in how citizens have the potential to contribute to-or even lead-the transition to more sustainable and just societies, by transforming patterns of everyday production, exchange, and consumption of goods and services $[7,8]$. This potential has been explored for cases both in the Global North and in the Global South [9]. These bottom-up innovation practices have also been studied across a wide range of sectors [10]: energy, e.g., community energy projects or energy cooperatives [11]; agro-ecology, e.g., self-consumption community gardens, food cooperatives, or food purchasing groups [12]; and eco-housing, e.g., low-impact and cooperative housing projects [13] and community currency [14]. Some works reveal not only the wide transformative potential of bottom-up innovations but also the relevance of public policies in order to support them-e.g., the case of European food cooperatives [15].

Grassroots innovations can be defined as "networks of activists and organisations generating novel bottom-up solutions for sustainable development" [13] (p. 585). They operate in the space of the social economy and are driven by unmet social needs and by the commitment to the transformation of systems. They frequently develop practices based on reordered priorities and alternative values. For example, they propose systems geared towards quality of life rather than economic growth per se. Thus, they propose alternative economic, social, and cultural expressions which favour localised, self-reliant economies as the basis of sustainable communities. Their organisational forms are very diverse: from cooperatives and associations to informal neighbourhood and community groups. Their resources do not come from commercial activity, but from voluntary work and sometimes from donations, public funds, or mutual exchanges [13].

The phenomenon has received attention by the community of scholars concerned with social innovation as a source of innovative solutions to social challenges [16,17]. It has been approached from various perspectives. Several discussions have been built on the bases of transitions theory $[8,16]$. More specifically, ideas from the multi-level perspective on socio-technical transitions have proven to be useful to understand the dynamics of grassroots innovations. These ideas-which are explored in the following section-are used to analyse how innovations can diffuse and disrupt existing socio-technical regimes through successful scaling up from niches of innovation. Socio-technical regimes are the dominant configurations of use of technologies, social practices, relations, rules, and discourses in process of production, distribution, and consumption (e.g., the agro-food regime is characterised by the focus on mechanisation, specialisation, increased inputs of energy and chemicals, concentration of power, and the goal of increasing productivity). Niches are alternative spaces in the margins, in which radical innovations emerge, experiment, and develop (e.g., local organic farming, based in diversity, circular use of inputs, and environmental sustainability). They can scale up and eventually influence or substitute regimes [8]. In any case, the idea of niche has become a pivotal category in the literature of grassroots innovation [8]. Existing literature has addressed issues such as how niches of innovation develop at the margins of systems [18]; the key reasons for its success or failure [19]; how niches emerge, diffuse, and influence a regime [20]; or how they eventually disrupt socio-technical systems [14]. In any case, there is a consensus that niches of grassroots innovations have the potential for building more just societies [7,9], as is the case of alternative lifestyle practices in general [2].

Some authors have explored these dynamics from a more explicit normative standpoint. For example, they have highlighted how grassroots innovations challenge power, dominant discourses, and social structures [7]; how equity issues are considered [21]; or how they confront neo-liberal perspectives and mobilise alternative values [22]. However, there is still a need for a deeper normative discussion, and there is a lack of clear criteria in the literature for discussing the performance of a given grassroots innovation $[23,24]$ in terms of the contribution to justice and in comparison to existing systems. There is a lack of a conceptual bases for this examination [25]. 
This gap regarding the theorisation of justice to address grassroots innovation is also present in the broader debates on social movements for environmental justice- - that is, the debates on the impacts on distribution, equity, participation, recognition, or well-being of processes driven by environmental movements [26]. In these conversations, "a small but critical group of scholars have begun to advocate the 'capabilities approach' to justice as conceptual scaffolding within which to theorize environmental justice" [26] (p. 755). The capability approach—which is explained in more depth below-is based in two core normative claims: On the one hand, it considers that the freedom to achieve well-being is of primary moral importance. On the other hand, it considers that this freedom is to be understood in terms of people's capabilities, that is, their real opportunities to do and be what they have reason to value. For this reason, the focus in normative analysis has to be put on the expansion on people's capabilities [27]. The capability approach has been celebrated for being useful to "conceptualize, measure, and assess the distribution of well-being", to provide "a normative basis for assessing the change or design of institutions, policies, and practices" [27] (p. 403), or to understand the connections between different disadvantages [28].

In the field of environmental justice, scholars have highlighted the potential of the capability approach to put the issue of well-being at the core; to adopt a multi-dimensional approach to justice [26]; to better address relations between the individual and the groups and between humans and non-humans—animals and systems—regarding justice [29]; or to go beyond utilitarianism [30]. However, capability scholars [31-33], as well as scholars specifically exploring the capability approach in environmental justice $[34,35]$, mostly agree that the approach is not a complete theory of justice and that it needs to be connected with other ideas.

Considering this, the aim of the paper is to propose and test a framework which can allow a normative analysis on how and in which sense a specific grassroots innovation contributes to the construction of a more just society. To this end, we first propose an original framework that connects elements from the capability approach and some other ideas by Sen with elements from the socio-technical transitions framework.

Second, we address two specific cases to apply and discuss the validity, scope, relevance, limits, and potential of the proposed framework. The cases are initiatives in two key sectors for sustainability - energy and food-in the city of Valencia (Spain). We essentially address the experience of participants, addressing how the cases under study may be contributing to more just societies though the processes of expansion of well-being in their environment.

The structure of this paper is as follows. Section 2 explains the proposed framework. Section 3 examines the methodology used to address the cases, which are introduced in Section 4. Findings are presented in Section 5 and discussed in Section 6. Lastly, Section 7 presents some final considerations regarding the aims of our study.

\section{Theoretical Framework}

\subsection{Socio-Technical Transitions and Grassroots Innovation}

The socio-technical transitions framework focuses on the transformation of the key features of systems of production and consumption such as food, transport, housing, finance, or energy. This literature is concerned with the characteristics and dimensions of systems and on the dynamics of change over time.

The multi-level perspective (MLP) organises the analysis of processes of innovation and change in systems by articulating the concepts of niches, regimes, and landscapes [36,37]. As Geels [38] (p. 26) pointed out, "MLP views transitions as non-linear processes that result from the interplay of developments at three analytical levels: niches (the locus for radical innovations), socio-technical regimes (the locus of established practices and associated rules that stabilize existing systems), and an exogenous socio-technical landscape". 
Socio-technical regimes form the deep structure that accounts for the stability of an existing socio-technical system [38]. They are stable and dominant ways of realising a particular societal function, that is, they are the dominant configurations of technologies, practices, stakeholder relations, discourses, etc. [37]. Regimes are constituted from a co-evolutionary accumulation and alignment of knowledge, objects, infrastructures, values, or norms. For example, the configuration of the agro-food regime we mentioned has been developed from the green revolution until nowadays. It has experienced incremental changes and realignments and, but has conserved its basic features.

According to Geels [38], there are several dimensions that characterise a given regime: its guiding principles (e.g., the overall assumptions driving the system); the technologies used; the industrial structure (e.g., the relationships between stakeholders in production processes); user relations and channels to access goods and services (e.g., infrastructure, modalities, and interactions for accessing); the policies and regulations (e.g., normative and legal aspects governing production, distribution, and consumption); the forms and sources of knowledge used, produced, and legitimised; and the culture (e.g., social and cultural patterns).

However, several socio-technical niches exist in a system: spaces in which alternative, less visible practices take place. They can be from labs and subsidised demonstration projects to community-led local initiatives and small market niches. These are protective spaces where different ideas, models, configurations, and ways of doing try to survive and develop. Niches are crucial for transitions, because they provide the seeds for systemic change. Actors developing niche practices (e.g., entrepreneurs, social enterprises, community or neighbourhood associations, and start-ups) work on radical innovations that deviate from existing regimes (e.g., for producing and marketing food differently) and hope that their novelties may eventually influence the regime or even replace it [38].

Niches present configurations whose characteristics are different to those of the regime: they may work with different principles; use different technologies; present different relations between stakeholders, channels, and user practices; or privilege different sources of knowledge and alternative cultures. Regimes are stable, whereas niches usually evolve quickly as they are spaces of experimentation and change [38]. Niches are the place of transformative ideas and practices, but their potential is constrained or enabled through the structures of the regime [37]. Regimes, thus, exert a structuring force on novel alternatives [37].

Following the ideas of the MLP [36,38], regimes try to survive and remain stable, but they are permanently exposed to pressures derived from external, powerful, and long-term economic, social, cultural, or environmental trends [39], which constitute the landscape. The socio-technical landscape is the wider context and includes aspects as "demographical trends, political ideologies, societal values, and macro-economic patterns" [38] (p. 28). Nevertheless, "this varied set of factors can be combined within a single 'landscape' category, because they form an external context that actors at niche and regime levels cannot influence in the short run" [38] (p. 28).

Transition in systems may take place when the regime is destabilised because of the pressure of the landscape, thus windows of opportunity may be open for niches-if they are mature enough - to influence or even completely replace the regime [35]. The landscape is, thus, the macro-level structuring context. For example, environmental crisis (landscape level) is pressing the agro-food socio-technical regime, thus creating the opportunity for some niche practices to grow and to produce changes in the regime (e.g., the growth of organic farming).

For some authors [13], grassroots innovation initiatives and networks configure innovation niches. In these niches, through community and citizen action, new ideas and models for the supply of goods and services are imagined, developed, and tested. The use of this framework helps to understand the dimensions, potential, limitations, and strategies of grassroots innovations to achieve structural transformation. 


\subsection{The Capability Approach: Contributions Towards a Normative Analysis of Social Justice of Grassroots Innovations}

To normatively analyse grassroots innovations, we may connect ideas on socio-technical transitions with ideas on justice coming from the vast literature on political philosophy. As is known, this literature spans methods from the classical approaches of utilitarianism or deontologism to the debates on distributive justice by Rawls, or those proposed by post-structuralist thinkers [40].

In this wide field, we consider the ideas on justice formulated by Sen in his capability approach to be relevant for addressing grassroots innovations for two main reasons, related with two key issues in the conceptualisation on justice [41].

The first concerns the why, that is, what has to be answered by a theory of justice. On this question, most modern theories, following the contractualist tradition of authors such as Locke, Rousseau, and Kant, aim to define how a perfect society and perfect institutions should be [42]. This is the approach followed by Rawls and by most modern theories of justice. On the other hand, a few theories, built on the tradition of Smith, Marx, and Mill [43], focus more on the existing injustice in the real world. The question here is not how a just society should be, but to "build a comparative approach that allows us to assess the justice of a situation or process by reference to other situations" [40]. This is the case of Sen's capability approach, which tries "to clarify how we can proceed to address questions of enhancing justice and removing injustice, rather than to offer resolutions of questions about the nature of perfect justice" [42] (p. 9). If we are aiming to assess specific changes in a given system, it seems appropriate to embrace a comparative theory of justice.

The second question concerns the what, that is, what counts as a matter of justice. On this issue, different theories have embraced different foci: e.g., the utilitarian focus on individual happiness or pleasure; the economic focus on the availability of resources; the focus on primary goods, by Rawls [44]; the focus on recognition proposed by post-structuralist thinkers [45]; the focus on justice in the processes of deliberation and communicative action [46]; or the focus on opportunities [47]. The latter is the case of the capability approach.

Capabilities are person's real freedoms or opportunities to achieve the life the person has reasons to value [48]. People may value different beings and doings, called by Sen functionings. They constitute what makes a life valuable for a person. Beings may include being well-nourished, being educated or being part of a supportive social network, for example. Doings may include travelling, caring for a child or taking part in a debate. They can be achieved because people have the capabilities. Whether or not they occur depends on personal choices [43]. In this way, Sen develops a multi-dimensional approach to justice which focuses on real ends (and not on means), and which assumes the plurality of life options and the complexity of processes for achieving what people have reason to value [49]. This approach may open the way for considering socio-technical configurations as enablers or disablers of human freedoms, from a plural perspective of human flourishing.

The capability approach evaluates processes according to their impact on what people are effectively able to do and be: their capabilities [50]. Sen [48] argued that evaluations should focus on capabilities and on removing obstacles so they can live the life they have reasons to value. In socio-technical transitions terms, the capability approach may evaluate the capabilities that people have (or that people value) in a given socio-technical configuration; that is, in a given structural condition.

There is a key distinction in the capability approach between means and capabilities. Means are goods and services, material or non-material inputs that can be of interest to people because they can expand their capabilities. Unlike other approaches, goods and services are not taken as ends in themselves. The important thing is the effect that means have on a person's ability to realise a capability [43]. For example, the relevant think is not just having resources as sanitation or doctors, but whether these resources are effectively leading to the capability to be healthy.

The relation between means and capabilities is captured with the idea of conversion factors. This refers to the degree in which a person can transform a resource into a capability. Conversion factors can be of different type: some are personal (e.g., physical condition, sex, and skills). For example, if a 
person is disabled or does not know how to ride a bike, then a bicycle will be not enable the capability of moving. Other factors are external and can be social, institutional, environmental, etc. (e.g., public policies, social norms, power relations, climate, and geographical location). For example, if there are no paved roads or if a social or legal norm considers that women are not allowed to cycle, then it becomes much more difficult to use the good in order to expand any capability [43].

In terms of justice, the capability approach normatively defines a space of evaluation, focusing on people's freedoms to achieve the life they value [43]. However, even if few scholars believe that Sen provides a full comparative theory of justice [30], most agree he provides a good basis but not a complete theory-including scholars on environmental justice [31-33,51]. For them, the capability approach essentially defines a clear space of evaluation to assess a process, policy, practice, institution, or organisational change [43], but to be a full theory of justice it would require further components and ideas.

Some scholars are specific on how to build a full theory of justice from the capability approach: for example, Nussbaum [33] (p. 33), one of the most reputed scholars of the capability approach, states: "capabilities can help us to construct a normative conception of social justice only if we specify a definite set of capabilities as the most important ones to protect". Other scholars analyse the potential and limits of Sen's ideas but propose different possibilities and avenues to build a full theory of justice $[26,27,31,32]$. We adopt this position, as it opens the way for a more specific exploration of a conceptualisation of justice for addressing grassroots innovation. Specifically, we share the considerations of Deneulin [31] in that we need both to build on other key ideas in Sen beyond capabilities, and that we have to bring new ideas to go beyond the limits of Sen's conceptualisation of justice. For Deneulin [31] (p. 789), Sen's "freedom-based conception of justice does not only have an opportunity aspect in the capability sense, it has also a process aspect in the agency sense, expressed through public reasoning. The opportunities that people have to live the kind of lives they have reasons to value are to be provided [ ... ] through processes of collective reasoning and decisions making". For Sen, "justice can only be assessed with the help of public reasoning", and that there are "different ways in which public reasoning has a key role in politics" [42] (p. 356). This means that all parties have to be heard, but also gives a central role to agency and to "political empowerment of the marginalized through political organisations so they can counteract the "bad" reasoning of the most powerful who make policy decisions that harm them" [31] (p. 791). Other scholars support this idea and consider that public reasoning in Sen goes beyond the Enlightenment idea of defending views to others with reasons, and points to the creation of "social and political climate in which critical thinking and free exchange of information and ideas among all individuals can flourish" [52] (p. 605).

It can, therefore, be said that an analysis of a given situation from Sen's ideas on justice would imply: first, an evaluation of the state of affairs in the capability space; and, second, an analysis of the different aspects of public reasoning processes [31].

However, even with these considerations on public reasoning, several authors point out that Sen's idea of justice still fails to recognise "the structuring conditions of a good life in common" [31] (p. 795); that is, whether the economic, cultural, and political structures modelling a given system are consistent with the good life for all. This means going beyond the analysis of public reasoning to address structural injustice. Therefore, to complete an analysis of justice of a given situation, a third aspect would then be necessary: the assessment of the structures of a given system to understand whether they are structuring conditions of a "good" society; that is, if they "provide the conditions for people to live flourishing human lives" [31] (p. 794).

These general reflections on the limits and potential of the capability approach to build a theory of justice are fully applicable in the case of the analysis of grassroots innovations. Sen's ideas provide a clear space of evaluation for these initiatives-the capabilities-which may provide the multi-dimensional approach to justice that scholars claim [26]. Nevertheless, for a full theory of justice, we may also take into account collective reasoning and decisions making processes in grassroots 
innovations, as well as how these innovations prefigure and advance structural transformations. These are questions that have been considered in the normative discussions on grassroots innovations [7].

\subsection{Connecting Frameworks}

Socio-technical transitions ideas may provide conceptual elements to understand the expansion of capabilities in their structural context. They can allow an analysis of structures and of structuring conditions for human flourishing in a given system: On the one hand, the comparative analysis of socio-technical configurations in regimes and in niches may help us understand the nature of existing structures and of future alternatives. On the other hand, the multi-level analysis of change may help us understand how landscape and regime operate as structuring structures that both limit and allow change undertaken by grassroots initiatives.

The connection between Sen's ideas and socio-technical transitions ideas can then help us to build a more compelling framework for the analysis of justice on three levels: first, the analysis of the evaluative space, by assessing which capabilities are grassroots innovation initiatives expanding through the creation of new means in alternative socio-technical configurations (that are not created in mainstream systems), and in whom they manifest. Second, the analysis of public reasoning, that is, the process of giving voices to the less empowered and of counteracting the "bad" reasoning of the most powerful, by understanding the process of the expansion of capabilities, the means created, and the factors at play. Third, the analysis of structures and structuring processes, by assessing the differences in socio-technical configurations in regimes and niches regarding the conditions for human flourishing, and by addressing how landscapes and regimes create structuring conditions for niches to develop.

Figure 1 shows the operationalisation of the ideas mentioned: in niches, alternative socio-technical configurations emerge. These configurations create the means for the expansion of capabilities of people operating in the niches, which are different from the capabilities of people operating in dominant regimes. Regimes and landscapes model and structure the process of expansion of capabilities, operating as external conversion factors together with personal conversion factors. More in general, they model public reasoning processes and the development of the niche.

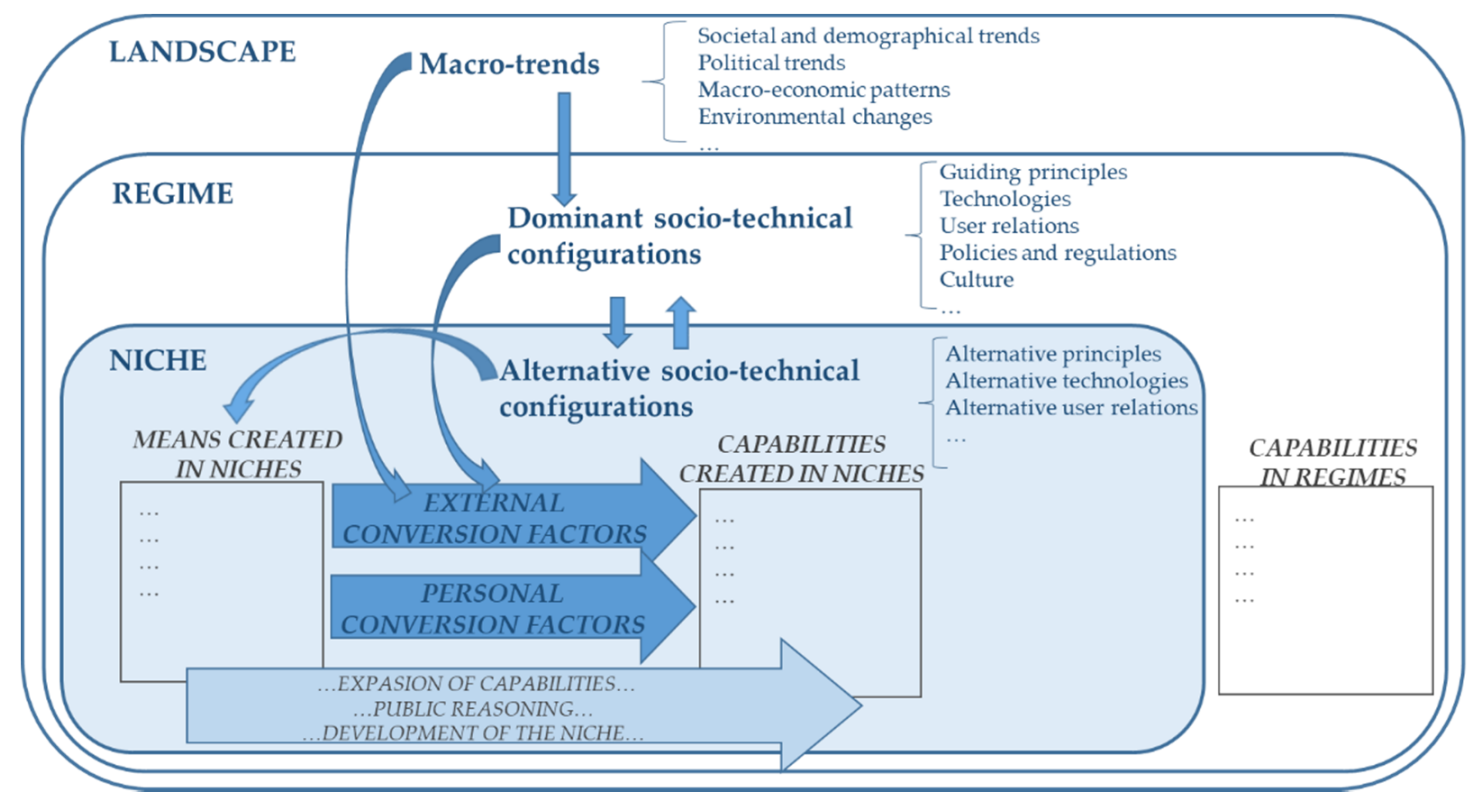

Figure 1. Theoretical framework for a normative analysis of grassroots innovations. 


\section{Materials and Methods}

Our study is based in the analysis of case studies. This methodological perspective is directed at assessing the scope, potential, and limitations of the proposed framework. To this end, a purposive selection has been made of cases that were accessible by researchers and which presented both common key features and also key differences that make the study of both cases relevant for the aims of our study.

Both cases are examples of grassroots innovation: community-led initiatives building alternative models of production, distribution, and consumption. They can be considered part of niches developing alternative socio-technical configurations in two key systems. In the food system, we explore the case of food purchasing groups in the city of Valencia (Spain) and its metropolitan area. In the energy system, we selected the case of Som Energia, an energy cooperative providing green energy to families and companies across the whole country (Spain).

These cases present key common characteristics: they are located in a country in which both sectors involve highly relevant experimentation at niche level and in which the landscape features people pressing hard for changes; both specific cases share and advocate similar objectives of transforming the systems; they have achieved a certain level of maturity (they have existed for at least five years and have experienced processes of rapid growth); and they are both not-for-profit initiatives. Beyond this, they operate in regimes in systems with significant differences in several dimensions, such as the policies, regulations, relationships between stakeholders, and the nature of the channels of provision.

We do not expect the cases in this study to be fully representative of the myriad possible grassroots innovations, nor is it within the scope of our research to provide empirical conclusions applicable to any case. Instead, we draw on the strengths of the analysis of critical case studies [53] to acquire relevant empirical elements that can be used to discuss the proposed framework, illustrate its potential and its limitations, as well as open up new avenues of research.

Our epistemological and ontological assumptions take elements from both interpretativist and critical paradigms [54]. We consider knowledge to be mediated by people's perspectives and interactions. However, we also consider knowledge to be mediated by the positions of people in social systems, and reality to be modelled by power relations and struggles within these systems [53]. Our aim is essentially exploratory, as we are proposing and empirically testing new theoretical propositions and new avenues. We adopted a purely qualitative methodological strategy aimed at capturing and understanding meanings, views, and frames [55].

Several methods for gathering information were used (see Table 1). First, we used secondary information: academic literature, along with documentary evidence from material produced by the cases themselves (such as websites and public statements), in order to address their stated values, aims, objectives, and perspectives. In the case of Som Energia, secondary information also provided information on issues as size, composition, resources, and ways of organising.

Second, we used information from participant observation for at least two years, with the aim of understanding their internal organisation and strategies of both cases. One of the authors participated in the meetings and assemblies of food groups. Another author participated in the general meetings, formative spaces, and conferences of Som Energia. Fieldnotes of different length were taken in each of the situations. These notes contain both descriptive and reflective information. All information gathered in the different situations was organised on the bases of the aspects mentioned in Table 1 in different document for each of the cases.

Third, we used individual interviews: in the case of the food groups, on the one hand, structured interviews were conducted with people from eight different groups, with specific questions directed at the origins, motivations and principles, size and composition, and ways of functioning and organising. For the selection of interviewees, we considered people with at least two years of continuous participation in the group and with a certain level of knowledge and engagement, so they could provide quality information on the aspects addressed in the interview. 
Table 1. Methods, data, and aspects addressed.

\begin{tabular}{|c|c|c|}
\hline Methods & Data Collected & Aspects Addressed \\
\hline \multicolumn{3}{|c|}{ Case 1: Food purchasing groups } \\
\hline $\begin{array}{l}\text { Documentary } \\
\text { evidence }\end{array}$ & $\begin{array}{l}\text { Websites of groups, appearance in media, flyers, } \\
\text { and dissemination material. }\end{array}$ & Stated values, aims, objectives, and perspectives \\
\hline Observation & $\begin{array}{c}\text { Participation in assemblies and in daily operation } \\
\text { of groups, assistance to spaces of coordination } \\
\text { between groups, assistance to roundtables and } \\
\text { debates with presence of groups. }\end{array}$ & $\begin{array}{l}\text { Internal organisation and procedures, relations, } \\
\text { key ideas used in internal, and external debates. }\end{array}$ \\
\hline \multirow[t]{2}{*}{$\begin{array}{l}\text { Individual } \\
\text { interviews }\end{array}$} & $\begin{array}{l}8 \text { structured interviews with people from } 8 \text { food } \\
\text { purchasing groups }\end{array}$ & $\begin{array}{c}\text { Origins, motivations, concerns and principles, } \\
\text { size, and composition, decision-taking process } \\
\text { and ways of functioning, resources, legal aspects, } \\
\text { activities developed. }\end{array}$ \\
\hline & $\begin{array}{l}9 \text { semi-structured interviews with people from } \\
1 \text { group }\end{array}$ & $\begin{array}{l}\text { Individual aspirations, drivers, experience, and } \\
\text { changes regarding participation in the group. }\end{array}$ \\
\hline \multicolumn{3}{|c|}{ Case 2: Som Energia Energy Cooperative } \\
\hline $\begin{array}{l}\text { Documentary } \\
\text { evidence }\end{array}$ & $\begin{array}{c}\text { Websites and blogs of Som Energia, public and } \\
\text { press statements. }\end{array}$ & $\begin{array}{l}\text { Stated values, aims, objectives, and perspectives. } \\
\text { Origins, motivations, concerns and principles, } \\
\text { size and composition, decision-taking process } \\
\text { and ways of functioning, resources, legal aspects, } \\
\text { activities developed. }\end{array}$ \\
\hline Observation & $\begin{array}{l}\text { Assistance to Som Energia main annual events } \\
\text { (addressed at members and open); assistance to } \\
\text { roundtables and debates with presence of } \\
\text { Som Energia }\end{array}$ & $\begin{array}{c}\text { Relations, key ideas used in internal and external } \\
\text { debates. }\end{array}$ \\
\hline $\begin{array}{l}\text { Semi-structures } \\
\text { interviews }\end{array}$ & $\begin{array}{l}9 \text { semi-structured interviews with people from } 6 \\
\text { local groups of Som Energia }\end{array}$ & $\begin{array}{c}\text { Internal organisation and procedures in local } \\
\text { groups, individual aspirations, drivers, } \\
\text { experience, and changes regarding participation } \\
\text { in the group. }\end{array}$ \\
\hline
\end{tabular}

Nine semi-structured interviews were carried out with people from one of these groups, with the objective of acquiring a better understanding of individual perspectives, motivations, aspirations, relations, and feelings regarding their participation in a group; the personal changes they claim to have undergone by taking part in the experiences; and the drivers of these changes. For the selection, we considered people with different levels of engagement (from low engagement and limited experience in the group to high engagement), in order to gather different perspectives regarding the aspects addressed. In the case of Som Energia, we used information from nine interviews with people in six different local groups, with the goal of better understanding the motivations, perspectives, and concerns of the local groups and also the individual processes of change regarding their participation. In this sense, we focused on people with a certain level of engagement in the cooperative, not people who were just using its services. Nevertheless, we also considered people with different levels of engagement. Interviews were recorded and lasted from 40 to 60 minutes. The general structure and contents of both structured and semi-structured interviews can be found in Appendix A.

The information was processed by means of a qualitative content analysis of documents, notes from observation and interviews. For the analysis, we drew on the predefined categories derived from our analytical framework presented in Section 2 in order to organise the information obtained on the different aspects addressed: dimensions of socio-technical regimes and niches (guiding principles, technologies used, user relations and channels, industrial structure, policies and regulations, sources of knowledge, and culture) and capabilities, means, and conversion factors modelling the expansion of capabilities (external factors from landscape and from regime and personal factors). During the analysis, subcategories inductively emerged from the data: subcategories regarding capabilities (material and non-material capabilities) and subcategories of means (mechanisms, protocols, and procedures; participation; alternative narratives and discourses; and networking and sharing). These categories and subcategories structured the characterisation of the cases (Section 4) and the presentation 
of the results of the study (Section 5). This allowed the comprehensive discussion regarding the outcomes, the process, and the conditions in the expansion of capabilities (Section 6), that is, in the creation of more just societies by the grassroots innovations under study.

\section{Case Studies Description}

\subsection{Food Purchasing Groups in Valencia}

Food purchasing groups can be considered as alternative initiatives challenging the conventional industrial regime of production, distribution, and consumption of food. Following Seyfang and Smith [13] and the dimensions proposed by Geels [38] for addressing socio-technical configurations, this regime is based in the principle of optimisation of outputs, in the intensive use of technology, and in an industrial structure based on specialisation, concentration, and large commercial operations. Commercialisation channels are concentrated in the hands of a few powerful stakeholders. Policies and regulations that sustain the regime answer to the needs of the big groups (e.g., public investment in biotechnology, barriers to short chains, and deregulation of global markets). The model is based on standardised techno-scientific knowledge, in fields such as biochemistry or logistics.

Food groups are part of a niche of alternative food networks. In this niche, various initiatives build models based more on organic, environmentally sustainable, democratic, socially responsible, and locally produced food [56]. This includes initiatives such as farmer's markets, box schemes, or food cooperatives [57]. This movement has been very active in the Spanish context [12,58]. Specifically, food purchasing groups have experienced significant growth in recent years. In Valencia and its metropolitan area, at least 14 groups were active in 2018, and 10 of them date back to 2011.

These initiatives are groups of people that self-organise in order to relocalise food systems [59]. They are volunteer based, organise democratically (usually in thematic working groups, such as economic management, relationships with producers, etc., as well as holding periodic assemblies to take important decisions), and establish direct relations with local producers to periodically order food, which is received at the group's premises and distributed among the members (usually weekly). The eight groups that were analysed have sizes of between 7 and 45 consumption units (units are families or groups of people living together), which usually have between two and three members each.

On the basis of the literature and the data gathered for this study, we can identify some key features of the alternative socio-technical practices that are built in the groups under study. Their guiding principle is to obtain responsible, sustainable, and healthy products. Technology is based on agro-ecological techniques (e.g., crop diversity and rotation, nutrient recycling, biological pest control, limited use of external inputs, etc.). The industrial structure calls for a diversity of stakeholders, small producers, and responsible local consumers. User relations and channels are based on short and local commercialisation chains, on lightly processed food, and on more conscious and reflective consumption. This alternative model calls for policies and regulations to support organic and local production and to facilitate alternative sales channels. These initiatives value farmers' local and embedded knowledge.

\subsection{Som Energia and Energy Cooperativism}

Renewable energy cooperatives are emerging in Spain as an alternative to the energy regime. Even though it is formally based on the principles of efficiency and the free market, the Spanish energy system has been heavily criticised for being unsustainable, opaque, and oligopolistic. Regarding the industrial structure and user relations, it is highly centralised in terms of generation, transport, distribution, and commercialisation. The price of energy is formally fixed by the market in daily energy auctions where producers and retailers meet (in fact, the only option for retail suppliers is to take part in this auction). However, in practice, these policies and regulations favour an oligopoly of only five companies that control $80 \%$ of the energy production and $95 \%$ of the commercialisation [60]. In terms of technology, the system is highly dependent on large investment and the use of fossil fuels over renewables and self-consumption installations [61]. Moreover, the system is based on expert and 
complex technological knowledge, and also on complex financial knowledge of market and tender mechanics for the daily energy price formation [62].

In this context, new citizen initiatives to produce and commercialise energy coming from renewable sources are arising in Spain, as is the case of the cooperative Som Energia. They call for a more democratic energy model and try to promote a new energy culture, based on transparency, energy efficiency, savings, and empowering the people [63].

Som Energia was created in 2010 and since then it has expanded exponentially across all of Spain. At the end of 2018, it already had more than 60,000 members. From the outset, the members of the cooperative have played a fundamental role in the development and in all decision-making processes. Evidence of this is the appearance of the "local groups", which are groups of committed activists that join together in their own local territory to organise conferences, debates, and regular meetings to both disseminate the products offered by the cooperative, and engage people to raise awareness about energy transition. They explain issues such as fuel poverty or revolving doors, and plan policy advocacy initiatives [64]. Beyond the local groups, other democratic spaces for decision-making exist within the cooperative at the national level: the governing council (elected volunteers who cannot occupy the position for more than four years) and the annual assembly. Beyond that, other spaces exist for discussion and formation, such as the local groups' annual meeting and September's Energy School.

The cooperative commercialises energy which is acquired in the daily energy auction and sold to members. However, it also supports local energy projects and carries out actions of lobbying and awareness-raising to change energy governance. Members of Som Energia can limit themselves to just buying energy, or engage more and take part in local groups, the assembly, or other activities by the cooperative.

In this way, the cooperative generates alternative socio-technical practices based on principles such as sustainability and democracy. It tries to build an industrial structure based on a more decentralised energy model. It not only creates an accessible channel for users, but also tries to move people from being mere clients to being an active part of the system. The politics and regulations demanded call for the promotion of self-consumption of clean energy, allowing local actors to participate in the market in conditions of equity, and for full transparency and accountability in mechanisms to fix energy prices. Furthermore, Som Energia tries to democratise knowledge, eliminate complex market mechanisms, simplify technology, and translate it into a vocabulary that can bring it closer to the public.

\section{Results}

\subsection{Capabilities Developed in People Engaged in the Cases Under Study}

We now try to identify which capabilities are created or expanded in people taking part in the practices under study (and which they consider that they cannot expand by accessing food or energy through the dominant systems). We refer to the two cases taken together, highlighting common issues and differences.

To begin with, most people taking part in one of the initiatives mention that they have the capability to access energy or food safely and easily, in the same way as when they used mainstream channels. However, people encounter a difference with regard to mainstream practices when they refer to their capability to access energy conveniently. The people taking part in Som Energia affirm that their energy bills are reduced because the cooperative offers information and education to help them make better decisions (e.g., on the kind of contract they have). Some people taking part in the food groups accept that they now pay more for some products, but that the information they now possess allows them make purchasing decisions (for example, buying more fresh food instead of processed products) that, in the end, reduce their overall monthly food expenditure.

People also refer to capabilities linked to non-material aspects. For example, the capability of critical thinking they have developed by participating in the food group or in the local group of Som 
Energia. They profess to having expanded their capability to critically examine the food or energy model, and make decisions based on this.

Another issue that is frequently mentioned connects material and non-material aspects: the capability to decide and control what they consume. People in food groups assume that this capability is almost fully developed, as long as the group (together with the food producers they partner with) fully controls the entire process of production and distribution of the food they eat. "For me, what we do is sovereignty ... to choose what you eat, what you produce, who you support ... and we can do this in the food group" (Interviewee, Food Group, 2). For people in Som Energia, they have a sense of control of the cooperative, but not of controlling the full process of energy production, distribution, and consumption, given the limitations of the system. The cooperative controls commercialisation, but they are still constrained to buy energy in the daily auction and to use the national network for distribution, so they still operate within a centralised system controlled by the oligopoly: "It's true that we had advanced in order to change the energy model [ ... ] But we have to recover our full [energy] sovereignty, and be able to produce our own energy" (Interviewee, Som Energia, 9).

This connects with another frequently mentioned issue: the ability to transform the model they operate in. In food groups, participants assume that group experiments with a fully transformed and different model. Their concern has more to do with its expansion: "We know that were are still a minority, a few tiny groups, which can hardly be an alternative. [... ] Another alternative schemes [for buying food] are necessary in order to arrive to more people" (IFG1). On the other hand, members of Som Energia do not feel that the cooperative is currently producing the full capacity for its members to operate in a completely different model. However, they consider that the cooperative is rapidly expanding the capability of many people to at least access energy in a much more democratic way, even if building a radically different system involves further changes that will entail a long struggle.

People from both initiatives also refer to issues connected with the capability to protect social and natural goods, with different emphases. In the case of food groups, nearly every interviewee refers to the capability the group brings to protect the territory of l'Horta, the rich agricultural landscape surrounding Valencia, where most of the food comes from and to which they feel a personal and emotional attachment. This is also linked to the capability to feel part of the territory. In the case of Som Energia, this issue is put in general and global terms by interviewees, having more to do with protecting the global environment and natural resources in general.

Analogous similarities and differences are found in relation to the capability to be part of a community, which is also frequently mentioned. By community, people from food groups refer not only to their own groups, but also to neighbourhoods or workplaces: "For me, the group was my family in the neighbourhood and my way of engaging when I arrived" (IFG3). In the case of Som Energia, this is not only linked to the idea of being part of a group of activists, but also, in broader terms, of a group of people sharing interests and concerns regarding the energy system. In relation to this, people frequently refer to a more instrumental issue, the capability to work in a group. They usually mention that being part of the grassroots initiative has not only expanded their ability to work efficiently, but has also provided them with a democratic and assembly-based perspective of joint work. "And then you realise that this is not about energy ... it is about what our role in society is. [ ... ] Who has the power? Who takes decisions? It is not about one energy source or another. It is about who decides that. If we want to change this, we first have to change how we relate to each other [... ] And we learn and we practice this in Som Energia" (ISE2).

In any case, differences in the capabilities mentioned are not only between the initiatives, but also between individuals. We return to this issue in the next section.

\subsection{Means Leading to the Expansion of Capabilities}

The analysis also reveals the key means created in niche practices that contribute to the emergence and expansion of the mentioned capabilities, and thus to more just situations. 
Most people refer to the importance of having clear mechanisms, protocols, and procedures. Even though participants in the initiatives try to build alternative consumption channels, they also value easy access to consumption. In this sense, Som Energia has established a very simple online system for becoming part of the cooperative. It also tries to facilitate and encourage members to participate in local groups, assemblies, and other democratic spaces. Likewise, the food groups try to develop clear and systematised working schemes and procedures, to contact farmers, receive and deliver food, and carry out more explicitly activist work. In any case, there are differences: Som Energia has paid staff that guarantees its daily operation, while consumer groups are based on activist work, which entails a significant effort for their members.

Both initiatives consider the fact that they are spaces of participation and democratic control to be of key importance. For the groups of people in both initiatives, participation is a question of coherence, but it also promotes exchange and discussion, facilitates learning, and creates friendship and confidence. These aspects are identified as central for expanding all of the capabilities mentioned. Several interviewees express themselves in similar terms: "it is by participating that we learn to participate, to transform, to build a different way of doing things".

Together with democratic spaces, people refer to a central means provided by the grassroots initiatives: the development of alternative narratives, discourses, terms, and ideas. They refer, for example, to the idea of "food sovereignty" or the discourse on a "new energy model". These narratives are considered very relevant for expanding the capabilities for transforming the system, for critical thinking and for working in groups. They are also central for building networks as they mobilise alliances on the bases of common frameworks.

Networks are in fact considered as another key means for capability expansion, for example, for developing critical thinking and the sense of belonging. Moreover, sharing experiences between initiatives also helps to improve procedures, and provides courage and inspiration. As a member of Som Energia indicates, by discovering different social initiatives in his territory, "I realised that we were changing things in the energy model [ ... ] that we can create a lot of pressure through our decisions about consumption [ ... ] that consumption is a powerful tool for social change" (ISE6).

Finally, food groups refer to a key means to expand capabilities which is not present in the case of Som Energia: the direct contact with producers: "The members who learn more are those in the working group who have continuous contact with the farmers providing us food [ ... ] In my case, this contact led me to a number of reflections on the problems and dynamics of the farmers and of l'Horta" (IFG6).

\subsection{Factors Modelling the Conversion of Means into Capabilities}

Regarding social external factors, elements derived from the pressures of the landscape have been of key importance, for example: the discrediting of big food and energy companies, scandals involving price fixing and the opacity of the big five energy corporations, public debates on the role of big food companies in food speculation, the destruction of local farming, and certain health crises. This has opened the space for the alternatives under study to be visible. However, certain institutional and policy features of the regimes continue to heavily limit the development of alternatives. This is particularly true in the case of energy, as the regulations firmly limit competency, local production, and decentralisation. In the case of food, bureaucracy and regulations make direct exchange between producers and consumers difficult, but it is much easier to operate, produce, and buy local food in various a-legal ways than in the case of energy.

Regarding other social factors, both experiences are limited by the very individualist mentality regarding the consumption of energy and food. This makes it very difficult to engage people in collective initiatives, unless they have an activist past, previous political awareness, or a strong motivation. In the case of Som Energia, only a small number of the members are in fact engaged in the local groups or participate in assemblies or other participatory spaces. In the case of food groups, every 
member has to be engaged in the daily workings of the group; however, this represents a significant disincentive for potential members, and thus a limitation for growth.

Some personal factors also play a key role. Previous activist experience seems to strongly model the kind of capabilities expanded. Results suggest that people with less experience in activism seem to have expanded capabilities which are less directly political, such as being part of a group, or taking care of the environment. On the other hand, people with more activist experience appear to expand capabilities more openly related with political issues, such as transforming the system. Beyond that, some other personal factors give the impression of being very necessary, such as the availability of time and flexibility to attend meetings. In fact, the people taking part in the initiatives are mostly young, well-educated, and middle-class-all factors that favour the possibility of engaging in the initiatives and meeting the demands of the time and effort required.

Table 2 summarises the main findings exposed in this section, regarding the capabilities, means and conversion factors at play in both case studies.

Table 2. Main findings: capabilities, means, and factors at play in grassroots innovations initiatives.

\begin{tabular}{|c|c|}
\hline \multicolumn{2}{|r|}{ Capabilities Expanded } \\
\hline Connected with material aspects & $\begin{array}{l}\text { Capability to access energy or food safely and easily } \\
\text { Capability to protect social and natural goods }\end{array}$ \\
\hline $\begin{array}{l}\text { Connected with non-material } \\
\text { aspects }\end{array}$ & $\begin{array}{l}\text { Capability of thinking critically } \\
\text { Capability to feel connected with territory } \\
\text { Capability to feel part of a community or group }\end{array}$ \\
\hline $\begin{array}{l}\text { Connected with material and } \\
\text { non-material aspects }\end{array}$ & $\begin{array}{l}\text { Capability to decide and to control what you consume. } \\
\text { Capability to transform the productive models }\end{array}$ \\
\hline \multicolumn{2}{|r|}{ Means } \\
\hline \multicolumn{2}{|c|}{$\begin{array}{c}\text { Clear mechanisms, protocols, and procedures of self-organisation, operation and consumption } \\
\text { Different spaces of participation and democratic control } \\
\text { Availability and development of alternative and transformative narratives, discourses, terms, and ideas } \\
\text { Networking and sharing with other initiatives and stakeholders }\end{array}$} \\
\hline \multicolumn{2}{|r|}{ Key conversion factors } \\
\hline External factors from landscape & $\begin{array}{l}\text { Discrediting of companies } \\
\text { Social reaction to speculation with public goods, oligopoly, and control } \\
\text { of value chains by big corporations. } \\
\text { Climate crisis }\end{array}$ \\
\hline External factors from regime & $\begin{array}{c}\text { Individualist mentality regarding consumption } \\
\text { Institutional and policy constraints for decentralised production and } \\
\text { distribution. }\end{array}$ \\
\hline Personal factors & $\begin{array}{l}\text { Previous activist experience } \\
\text { Availability of time and flexibility } \\
\text { Age, education, and social class. }\end{array}$ \\
\hline
\end{tabular}

\section{Discussion}

Drawing on the framework proposed and on the empirical results, we highlight several aspects regarding how the cases contribute to justice, addressing three levels.

First, regarding the evaluative space of capabilities, the initiatives are expanding multiple capabilities in the people engaged in them, capabilities that were not available to these people when they operated under the dominant socio-technical practices. For example, people now feel to have expanded their capability of critical reflection, of being part of a community, of transforming the systems they live in, or of protecting natural goods. This expansion is multi-dimensional, as these capabilities go well beyond the purely material aspects of human flourishing to connect with political, ethical, emotional, and spiritual dimensions. Moreover, they do not only refer to relations between humans, but also between humans and non-humans. For example, by meeting and supporting local 
farmers people not only conveniently access quality food, but also develop a sense of belonging to the place, of taking care of the local ecosystems and the natural territory of l'Horta.

Second, the initiatives contribute to public reasoning in several aspects, as the analysis of capabilities, means and factors suggest. The cases politically empower and promote the agency of certain groups excluded from decisions of dominant food and energy systems-even though some of them would not appear to be among the most excluded groups in society, e.g., non-organised consumers, people looking for transformation through consumption, and small local farmers. The initiatives create means for collective action and contribute towards counteracting the dominant arguments in public spheres of powerful stakeholders (such as big food companies and the oligopolistic energy enterprises), by creating and testing alternative narratives, discourses, terms, and ideas. Moreover, they create and negotiate these ideas and practices in open and democratic spaces of interaction, which connect consumers together, and also with producers and initiatives of differing natures. The initiatives deploy public reasoning processes, but also generate relevant outputs for public reasoning, as they create capabilities such as critical thinking, feeling part of the community, taking decisions on consumption that favour others and the environment, etc. However, evidence also reveals the limits of these processes, such as the difficulties in actively engaging or mobilising people with no history of activism.

Third, the analysis suggests that the grassroots organisations under study create and prefigure alternative socio-technical configurations that provide better conditions for human flourishing for all. As shown, the initiatives point towards more localised, decentralised, diversified, inclusive, democratised, and fair systems. These structures create better structural conditions for a good life than the existing dominant regimes, focused on optimising profits, maintaining these controlling processes, and the concentration of power and operations. Moreover, the analysis shows how structural change may take place: the existing regime and landscape function as structures that limit as well as allow spaces for change. For example, the concentration of resources in few powerful stakeholders or the rigid regulations structurally limit the action of grassroots, but the situation of loss of legitimacy of these stakeholders and the impact of climate crisis (among other processes) open windows of opportunity for articulating mobilising discourses and for the development of alternatives.

\section{Conclusions}

The paper attempts to propose and test a framework to assess the contribution of grassroots innovations to more just societies in alternative everyday life practices. We draw on Sen's ideas on justice, identify its limits and try to go beyond them by combining elements from the capability approach with the socio-technical transitions literature in order to propose a compelling comparative theory of justice. Our proposal puts capabilities at the core, as an evaluative space, but also considers public reasoning processes and the nature of structures to secure a good life for all.

The application of the framework suggests that these grassroots innovations may be valuable for justice for different reasons: they contribute to multi-dimensional human flourishing (and also to the flourishing of relations between humans and non-humans); they improve public reasoning processes by creating counter-narratives, democratic spaces, and new capabilities for reasoning and mobilisation; and they create better structural conditions for human flourishing for all through the creation of more diversified, decentralised, and democratic systems. These process takes place in complex and dynamic ways, modelled by existing structures that limit but also present opportunities for change. Nevertheless, our exploration also reveals some tensions regarding the contribution to justice of the initiatives: for example, most members are not among the most excluded groups in society. Moreover, individuals with more time and flexibility and with previous experience benefit more from the initiatives. 
The theory and methods used in our exploration show some limits that can be addressed in future research. Firstly, our study mainly addresses the experiences of participants of the initiatives. For this reason, it does not fully capture the direct impacts on other key stakeholders (for example, farmers or other people in the communities in which the initiatives operate). In future research, it would be interesting to approach other stakeholders and documentary sources, in order to have a broader picture of the contribution to justice of particular initiatives. Secondly, results reveal the crucial role of relations within initiatives and between initiatives and their environment. Nevertheless, these dynamics are not fully captured by the framework. Moreover, the framework and research design does not put the focus in the differences between individuals. For this reason, they could be enriched to better understand these dynamics and differences in other initiatives and sectors. For this aim, the use of more elements coming from strategic niche management literature could be explored.

In any case, the paper illustrates the potential of the dialogue between the capability approach and innovation studies to better understanding and assess the transformative processes promoted by movements creating alternative everyday life practices. The paper also illustrates that this exploration may be very relevant for the debates on the capability approach and justice, and for the discussions on the contribution of social movements to environmental justice.

Author Contributions: Conceptualisation, S.B.-M., V.P.-S., and A.B.; methodology, S.B.-M.; software, S.B.-M. and V.P.-S.; formal analysis, S.B.-M.; investigation, S.B.-M. and V.P.-S.; resources, S.B.-M. and V.P.-S.; data curation, S.B.-M. and V.P.-S.; writing - original draft preparation, S.B.-M. and V.P.-S.; writing-review and editing, S.B.-M. and A.B.; visualisation, S.B.-M.; supervision, A.B.; project administration, S.B.-M.; and funding acquisition, A.B. All authors have read and agreed to the published version of the manuscript.

Funding: This research was funded by the Ministerio de Economía, Industria y Competitividad, Plan Estatal de Investigación, grant number CSO2013-41985-R.

Acknowledgments: We thank Valencian food groups, Som Energia, Utópika, ISF-Valencia and the Plataforma per la Sobirania Alimentària del País Valencià, along with all the people who participated in the study. We also thank James Hunt for the proofreading and Adrian Smith for his advice and support in this research.

Conflicts of Interest: The authors declare no conflict of interest. The funders had no role in the design of the study; in the collection, analyses, or interpretation of data; in the writing of the manuscript, or in the decision to publish the results.

\section{Appendix A}

Interviews' scripts

Structured interview to members of food purchasing groups script

Key topics addressed in the interview:

- $\quad$ Area in which the group is operating.

- $\quad$ Time and process of creation of the group.

- $\quad$ Number of consumption units/families.

- $\quad$ Average number of people in each unit.

- General profile of members (age, origin, occupation).

- $\quad$ Frequency of delivery of products.

- Number of consumption units/families ordering food frequently.

- Legal form.

- Criteria used to select products and producers.

- Products available.

- Number and type of producers serving the food.

- $\quad$ Process for entering the group.

- $\quad$ Level of commitment of members. 
- $\quad$ Distribution of tasks.

- Number, name and tasks of working groups.

- $\quad$ Processes for decisions taking.

- $\quad$ Frequency and protocols for meetings and assemblies.

- $\quad$ Procedure for ordering, receiving and delivering the food.

- $\quad$ Tools for managing food orders.

- Premises in which meetings and delivery of food is developed and how. Owner of the premises and relation with the group. Conditions of use.

- $\quad$ Activities developed (beyond ordering and distributing food).

Semi-structured interview to members of food purchasing groups script

Key topics addressed in the interview:

1. Which were your original motivations to join the food group?

2. How was your past and how is your present involvement in the group?

3. How do you see the social and environmental role and importance of the group?

4. How would you describe the way of functioning and the relations in the group?

5. How would you describe your personal relations and your feelings regarding the group?

6. What the group has provided you, in terms of opportunities, learning or personal change?

7. Which aspects regarding how the group works have helped you in order to learn, change or improve your opportunities?

8. How do you see the future of the group and your future regarding the group?

Semi-structured interview to members of Som Energia local groups script

Key topics addressed in the interview:

1. How do you work in your local group of Som Energia (internal organization, frequency of meetings, number of people assisting, specific activities developed)?

2. Which were your original motivations to join Som Energia?

3. How was your past and how is your present involvement in the cooperative?

4. How do you see the social and environmental role and importance of the cooperative?

5. How would you assess the way of functioning and the relations in the cooperative?

6. How would you describe your relations and your feelings regarding the cooperative?

7. What your involvement in Som Energia has provided you in terms of opportunities, learning or personal change?

8. Which aspects regarding how Som Energia and how your local group work have helped you in order to learn, change or improve your opportunities?

9. How you see the future of the cooperative and your future regarding the cooperative?

\section{References}

1. Bennett, W.L. The personalization of politics: Political identity, social media, and changing patterns of participation. Ann. AAPSS 2012, 644, 20-39. [CrossRef]

2. De Moor, J.; Marien, S.; Hooghe, M. Why only some lifestyle activists avoid state-oriented politics: A case study in the Belgian environmental movement. Mobilization 2017, 22, 245-264. [CrossRef]

3. Eckersley, R. Ecological democracy and the rise and decline of liberal democracy: Looking back, looking forward. Environ. Politics 2020, 29, 214-234. [CrossRef]

4. Micheletti, M.; Stolle, D. Vegetarianism-A lifestyle politics? In Creative Participation Responsibility-Taking in the Political World; Micheletti, M., McFarland, A.S., Eds.; Paradigm: Boulder, CA, USA, 2011.

5. Giddens, A. Modernity and Self-Identity. Self and Society in the Late Modern Age; Polity: Cambridge, UK, 1991.

6. Yates, L. Everyday politics, social practices and movement networks: Daily life in Barcelona's social centres. Br. J. Sociol. 2015, 66, 236-258. [CrossRef] 
7. Smith, A.; Hargreaves, T.; Hielscher, S.; Martiskainen, M.; Seyfang, G. Making the most of community energies: Three perspectives on grassroots innovation. Environ. Plan. A 2015, 48, 407-432. [CrossRef]

8. Hossain, M. Grassroots innovation: A systematic review of two decades of research. J. Clean. Prod. 2016, 137, 973-981. [CrossRef]

9. Pansera, M.; Sarkar, S. Crafting sustainable development solutions: Frugal innovations of grassroots entrepreneurs. Sustainability 2016, 8, 51. [CrossRef]

10. Hossain, M. Grassroots innovation: The state of the art and future perspectives. Technol. Soc. 2018, 55, 63-69. [CrossRef]

11. Hargreaves, T.; Hielscher, S.; Seyfang, G.; Smith, A. Grassroots innovations in community energy: The role of intermediaries in niche development. Glob. Environ. Chang. 2013, 23, 868-880. [CrossRef]

12. Pellicer-Sifres, V.; Belda-Miquel, S.; López-Fogués, A.; Boni Aristizabal, A. Grassroots social innovation for human development: An analysis of alternative food networks in the city of Valencia (Spain). J. Hum. Dev. Capab. 2017, 8, 258-274. [CrossRef]

13. Seyfang, G.; Smith, A. Grassroots innovations for sustainable development: Towards a new research and policy agenda. Environ. Polit. 2007, 16, 584-603. [CrossRef]

14. Seyfang, G.; Longhurst, N. Desperately seeking niches: Grassroots innovations and niche development in the community currency field. Glob. Environ. Chang. 2013, 23, 881-891. [CrossRef]

15. Bijman, J.; Iliopoulos, C. Farmers' cooperatives in the EU: Policies, strategies, and organization. Ann. Public Coop. Econ. 2014, 85, 497-508. [CrossRef]

16. Van der Have, R.P.; Rubalcaba, L. Social innovation research: An emerging area of innovation studies? Res. Policy 2016, 45, 1923-1935. [CrossRef]

17. Nicholls, A.; Simon, J.; Gabriel, M.; Whelan, C. New Frontiers in Social Innovation Research; Springer: Houndmills, UK, 2015.

18. Ornetzeder, M.; Rohracher, H. Of solar collectors, wind power, and car sharing: Comparing and understanding successful cases of grassroots innovations. Glob. Environ. Chang. 2013, 23, 856-867. [CrossRef]

19. Feola, G.; Nunes, R. Success and failure of grassroots innovations for addressing climate change: The case of the transition movement. Glob. Environ. Chang. 2014, 24, 232-250. [CrossRef]

20. Zapata Campos, M.J.; Zapata, P. Infiltrating citizen-driven initiatives for sustainability. Environ. Polit. 2017, 26, 1055-1078. [CrossRef]

21. Schot, J.; Steinmueller, W.E. Three frames for innovation policy: R\&D, systems of innovation and transformative change. Res. Policy 2018, 47, 1554-1567.

22. Martin, C.J.; Upham, P. Grassroots social innovation and the mobilisation of values in collaborative consumption: A conceptual model. J. Clean. Prod. 2016, 134, 204-213. [CrossRef]

23. Turnheim, B.; Berkhout, F.; Geels, F.; Hof, A.; McMeekin, A.; Nykvist, B.; van Vuuren, D. Evaluating sustainability transitions pathways: Bridging analytical approaches to address governance challenges. Glob. Environ. Chang. 2015, 35, 239-253. [CrossRef]

24. Jenkins, K.; Sovacool, B.K.; McCauley, D. Humanizing sociotechnical transitions through energy justice: An ethical framework for global transformative change. Energy Policy 2018, 117, 66-74. [CrossRef]

25. Geels, F.W. The multi-level perspective on sustainability transitions: Responses to seven criticisms. Environ. Innov. Soc. Transit. 2011, 1, 24-40. [CrossRef]

26. Edwards, G.A.; Reid, L.; Hunter, C. Environmental justice, capabilities, and the theorization of well-being. Prog. Hum. Geogr. 2016, 40, 754-769. [CrossRef]

27. Robeyns, I. Capabilitarianism. J. Hum. Dev. Capab. 2016, 17, 397-414. [CrossRef]

28. Wolff, J.; de-Shalit, A. Disadvantage; Oxford University Press: Oxford, UK, 2007.

29. Schlosberg, D.; Carruthers, D. Indigenous struggles, environmental justice, and community capabilities. Glob. Environ. Polit. 2010, 10, 12-35. [CrossRef]

30. Ballet, J.; Koffi, J.M.; Pelenc, J. Environment, justice and the capability approach. Ecol. Econ. 2013, 85, 28-34. [CrossRef]

31. Deneulin, S. Development and the limits of amartya sen's the idea of justice. Third World Q. 2011, 32, 787-797. [CrossRef]

32. Robeyns, I. Equality and justice. In An Introduction to the Human Development and Capability Approach: Freedom and Agency; Deneuilin, S., Shahani, L., Eds.; Earthscan: London, UK, 2009. 
33. Nussbaum, M. Capabilities as fundamental entitlements: Sen and social justice. Fem. Econ. 2003, 9, 33-59. [CrossRef]

34. Walker, G. Environmental justice and normative thinking. Antipode 2009, 41, 203-205. [CrossRef]

35. Schlosberg, D. Defining Environmental Justice: Theories, Movements, and Nature; Oxford University Press: Oxford, UK, 2007.

36. Geels, F.W. Ontologies, socio-technical transitions (to sustainability), and the multi-level perspective. Res. Policy 2010, 39, 495-510. [CrossRef]

37. Smith, A.; Vo $\beta$, J.P.; Grin, J. Innovation studies and sustainability transitions: The allure of the multi-level perspective and its challenges. Res. Policy 2010, 39, 435-448. [CrossRef]

38. Geels, F.W. Technological transitions as evolutionary reconfiguration processes: A multi-level perspective and a case-study. Res. Policy 2002, 31, 1257-1274. [CrossRef]

39. Rotmans, J.; Kemp, R.; Van Asselt, M. More evolution than revolution: Transition management in public policy. Foresight 2001, 3, 15-31. [CrossRef]

40. Moragues-Faus, A. Problematising justice definitions in public food security debates: Towards global and participative food justices. Geoforum 2017, 84, 95-106. [CrossRef]

41. Gasper, D. The Ethics of Development. From Economicism to Human Development; Edimburgh University Press: Edimburgh, UK, 2004.

42. Sen, A. The Idea of Justice; Harvard University Press: Cambridge, MA, USA, 2009.

43. Robeyns, I. The capability approach: A theoretical survey. J. Hum. Dev. Capab. 2005, 6, 93-117. [CrossRef]

44. Rawls, J. A Theory of Justice; Harvard University Press: Cambridge, MA, USA, 2009.

45. Fraser, N. Escalas de Justicia; Herder: Barcelona, Spain, 2008.

46. Habermas, J. Teoría de la Acción Comunicativa; Taurus: Madrid, Spain, 1987.

47. Gasper, D. What is the capability approach? Its core, rationale, partners and dangers. J. Socio-Econ. 2007, 36, 335-359. [CrossRef]

48. Sen, A. Development as Freedom; Oxford Paperbacks: Oxford, UK, 2001.

49. Alkire, S.; Deneulin, S. Introducing the Human Development and Capability Approach; Earthscan: London, UK, 2009.

50. Muraca, B. Towards a fair degrowth-society: Justice and the right to a "good life" beyond growth. Futures 2012, 44, 535-545. [CrossRef]

51. Claassen, R. An agency-based capability theory of justice. Eur. J. Philos. 2017, 25, 1279-1304. [CrossRef]

52. Osmani, S.R. Theory of justice for an imperfect world: Exploring Amartya Sen's idea of justice. J. Hum. Dev. Capab. 2010, 11, 599-607. [CrossRef]

53. Flyvbjerg, B. Five misunderstandings about case-study research. Qual. Inq. 2006, 12, 219-245. [CrossRef]

54. Lincoln, Y.S.; Lynham, S.A.; Guba, E.G. Paradigmatic controversies, contradictions, and emerging confluences, revisited. In The Sage Handbook of Qualitative Research; Denzin, N., Lincoln, Y.S., Eds.; SAGE: London, UK, 2011; Volume 4, pp. 97-128.

55. Corbetta, P. Metodología y Técnicas de Investigación Social; McGraw-Hill Interamericana de España: Barcelona, Spain, 2003.

56. Goodman, D.; DuPuis, E.M.; Goodman, M.K. Alternative Food Networks: Knowledge, Practice, and Politics; Routledge: London, UK, 2012.

57. Seyfang, G.; Haxeltine, A. Growing grassroots innovations: Exploring the role of community-based initiatives in governing sustainable energy transitions. Environ. Plan. C 2012, 30, 381-400. [CrossRef]

58. Díaz, E.C. El enfoque del decrecimiento como estrategia de empoderamiento y transformación social. Estudio de caso de los grupos de consumo agroecológico de Granada (España). Tsg Trab. Soc. Glob. Soc. Work. 2014, 4, 49-71.

59. Vivas, E. El consum agroecològic a l'Estat espanyol: Una opció política. In Reflexions Sobre Les Alimentacions Contemporànies; Medina, F.X., Ed.; Universitat Oberta de Catalunya: Barcelona, Spain, 2010.

60. APPA. Asociación de Empresas de Energía Renovables. In Estudio del Impacto Macroeconómico de las Energías Renovables en España; APPA: Madrid, Spain, 2013.

61. Sanchez-Herrero, M. Consecuencias económicas del modelo energético. In Alta Tensión: Por un Nuevo Modelo Energético Sostenible, Democrático y Ciudadano; Icaria: Madrid, Spain, 2014.

62. Latonda, M.A. El Sistema de Intermediación de Intereses y Los Grupos de Interés en el Sector Eléctrico Español. Ph.D. Thesis, Universitat de València, Valencia, Spain, 6 May 2014. 
63. Som Energia, Qui Som? Available online: https://www.somenergia.coop/ca/qui-som/\#quefem (accessed on 10 November 2019).

64. Riutort, S. Reapropiación Popular de la Eenergía en los Albores de una Transición Incierta. Una Contribución a Partir del Análisis de Caso de Som Energia. Ph.D. Thesis, Universitat de Barcelona, Barcelona, Spain, 21 December 2015.

(c)

(C) 2020 by the authors. Licensee MDPI, Basel, Switzerland. This article is an open access article distributed under the terms and conditions of the Creative Commons Attribution (CC BY) license (http://creativecommons.org/licenses/by/4.0/). 